\title{
Modification of the Al-9\%SiMg Alloy with Aluminum, Boron, and Titanium Fast Cooled Mixtures
}

\author{
T. LIPIŃSKI* \\ University of Warmia and Mazury in Olsztyn, Faculty of Technical Sciences, \\ St. Oczapowskiego 11, 10-957 Olsztyn, Poland
}

\begin{abstract}
The mechanical properties of hypoeutectic silumins can be improved through chemical modification as well as chemical elements or technological processing. This study presents the results of modification of an $\mathrm{Al}-9 \% \mathrm{SiMg}$ alloy with aluminium, boron, and titanium. The experiments were conducted following a factor design $2^{3}$ for 3 independent variables. The influence of the analyzed modifiers on the microstructure and mechanical properties of the processed alloy was presented in graphs. The modification of a hypoeutectic Al-9\% SiMg alloy improved the alloy's properties. The results of the tests indicate that the mechanical properties of the modified alloy are determined by the components introduced to the alloy.
\end{abstract}

DOI: 10.12693/APhysPolA.130.982

PACS/topics: $81.40 .-\mathrm{z}$

\section{Introduction}

Hypo-eutectic silumins are a popular group of casting alloys owing to their relatively low price, low melting temperature, low density, good electric and thermal conductivity, high resistance to corrosion and high strength relative to specific gravity. Those attributes have contributed to the wide use of hypo-eutectic silumins in aviation, motor, and ship building industries [1-3].

In hypo-eutectic alloys of aluminum and silicon, solid solution dendrites which crystallize first are typical crystals, showing isotropic properties $[2,4]$. Similarly to pure aluminum, solid solution $\alpha$ (silicon in aluminum) has a regular cubic face-centered lattice of the type A1. The growth rate of those crystals, and the growth rate of eutectic mixture crystallizing at the next stage $(\alpha+\beta)$ is a function of supercooling at the crystallization front. This dependence is a complex function of: the chemical composition of the liquid and solid phase, surface curvature of the crystallization front, crystallization heat emission, and structural defects $[2,5]$.

The mechanical properties of hypo-eutectic silumins can be improved through modification as well as traditional or processing. Several modifiers are known (e.g., strontium, antimony, sodium, barium, calcium), of which strontium is the most frequently used in the $\mathrm{Al}-\mathrm{Si}$ alloy industry because it is easy to handle, has a good modification rate, a long incubation time and a low fading effect [6-12]. Modification improves the material's mechanical properties through grain refinement. Other interesting methods of modifying hypo-eutectic silumins involve the use of homogeneous modifiers [7] as well as modifiers that produce exothermic effects [8]. The interactions between "opposing" chemical elements used as

\footnotetext{
* corresponding author; e-mail: tomekl@uwm.edu.pl
}

modifying agents may have an adverse effect on successive alloy modifications. An example may be the interactions between $\mathrm{Sb}$ and $\mathrm{Sr}$, and between $\mathrm{Sb}$ and $\mathrm{Na}$, which are a serious concern during further processing of modified alloys [1, 12-16].

In view of the growing popularity of modified alloys, the aim of this study was to determine the mechanical properties of hypo-eutectic silumins $\mathrm{Al}-9 \% \mathrm{SiMg}$ modified with aluminum, boron, and titanium fast cooled mixtures.

\section{Materials and methods}

The experimental material was Al-9\% SiMg alloy which was regarded as representative of hypoeutectic silumins. The alloy was obtained from industrial piglets. The alloy was melted in an electric furnace, and the modification process was carried out with $\mathrm{Al} \in\langle 1,5\rangle[\%]+\mathrm{B} \in$ $\langle 0.04,0.08\rangle[\%]$ and $\mathrm{Ti} \in\langle 0.1,0.5\rangle[\%]$ by weight. To obtain a modifier, Al-Si alloy was melted and then cooled on a metal plate at rate about $50^{\circ} \mathrm{C} / \mathrm{s}$. This enabled to produce component, which were refined immediately before adding to the alloy. The alloy was modified at a temperature of $850^{\circ} \mathrm{C}$ for $5 \mathrm{~min}$. The $2^{3}$ factorial design with three independent variables was applied. The results were analyzed mathematically, which enabled to formulate the factor equation for three variables, for the parameters studied, at the level of significance $=0.05$. The adequacy of the above mathematical equation was verified using the Fischer criterion for $p=0.05$.

Cylindrical samples, $8 \mathrm{~mm}$ in diameter and $75 \mathrm{~mm}$ in length, were poured into a mold made of molding sand. Casts were removed from molds, and specimens were collected for mechanical tests. Hardness was determined by the Brinell method by applying a test load of $612.9 \mathrm{~N}$ to a ball with a diameter of $2.5 \mathrm{~mm}$. The side surface of the head of the specimen used in a static tensile test was ground to a depth of $2 \mathrm{~mm}$. Three measurements 
were taken per sample (6 measurements per cast). All measurements were carried out according to standard PN-EN 6506-1:2008 "Metallic materials. Brinell hardness test. Part 1: Testing methodology" in the HPO 250 hardness tester. The tensile stress test was performed on a specimen with a length-to-diameter ratio of 5:1 in the ZD-30 universal tensile tester. Ultimate tensile strength and percentage elongation were determined. A tensile strength test was performed on two samples, $\phi 6 \mathrm{~mm}$, for each melting point, according to standard PN-EN 6892-1: 2010 "Metallic materials. Tensile testing. Part 1: Testing methodology at room temperature".

\section{Results}

The chemical composition of the $\mathrm{Al}-9 \% \mathrm{SiMg}$ alloy is presented in Table I. The example of presence of modifying elements in the alloy was confirmed by quantitative X-ray analysis (Fig. 1) and parameters of phases in Table II. The ultimate tensile strength (UTS) of the Al$9 \% \mathrm{SiMg}$ alloy after chemical treatment is presented in Fig. 2. Percentage elongation $(A)$ of the Al-9\%SiMg alloy after chemical treatment is shown in Fig. 3. The Brinell hardness of the $\mathrm{Al}-9 \% \mathrm{SiMg}$ alloy after chemical treatment is presented in Fig. 4.

TABLE I

Chemical composition [wt.\%] of the $\mathrm{Al}-9 \% \mathrm{SiMg}$ raw alloy

\begin{tabular}{c|c|c|c|c|c|c|c|c}
\hline \hline $\mathrm{Si}$ & $\mathrm{Cu}$ & $\mathrm{Mg}$ & $\mathrm{Mn}$ & $\mathrm{Fe}$ & $\mathrm{Ti}$ & $\mathrm{Zn}$ & $\mathrm{Ni}$ & $\mathrm{Al}$ \\
\hline 8.9 & 0.17 & 0.24 & 0.30 & 0.40 & 0.10 & 0.15 & 0.01 & bal.
\end{tabular}

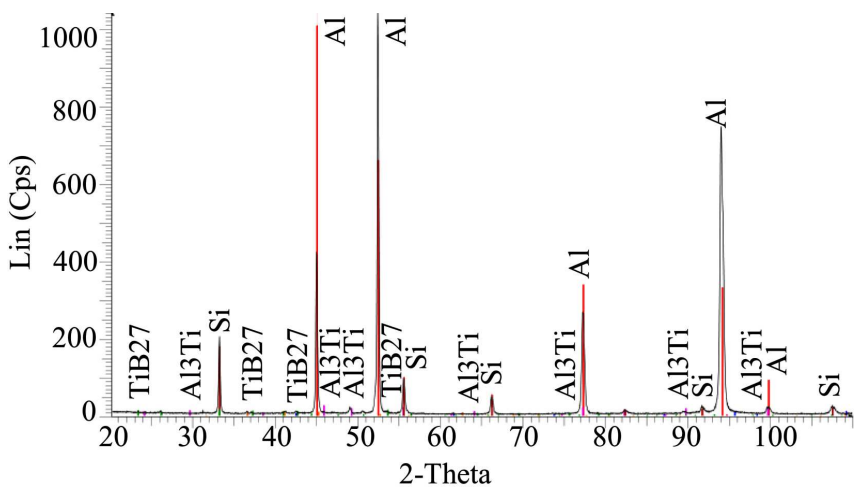

Fig. 1. Quantitative X-ray analysis of the Al-9\% SiMg alloy with $5 \% \mathrm{Al}+0.08 \% \mathrm{~B}+0.5 \% \mathrm{Ti}$.

TABLE II

X-ray analysis parameters of the $\mathrm{Al}-9 \% \mathrm{SiMg}$ alloy with $5 \% \mathrm{Al}+0.08 \% \mathrm{~B}+0.5 \% \mathrm{Ti}$

\begin{tabular}{c|c|c|c|c|c}
\hline \hline Phase & $a$ & $C$ & $z$ & Space group & Lattice \\
\hline $\mathrm{Al}$ & 4.04940 & & 4 & $14 / \mathrm{mmm}(139)$ & face-centered cubic \\
\hline $\mathrm{Si}$ & 5.43029 & & 8 & P42nnm (134) & face-centered cubic \\
\hline $\mathrm{Al}_{3} \mathrm{Ti}$ & 3.84400 & 8.59600 & 4 & Fm-3m (225) & body-centered tetragonal \\
\hline $\mathrm{TiB}_{27}$ & 8.83000 & 5.07200 & 1 & Fd-3m (227) & tetragonal
\end{tabular}
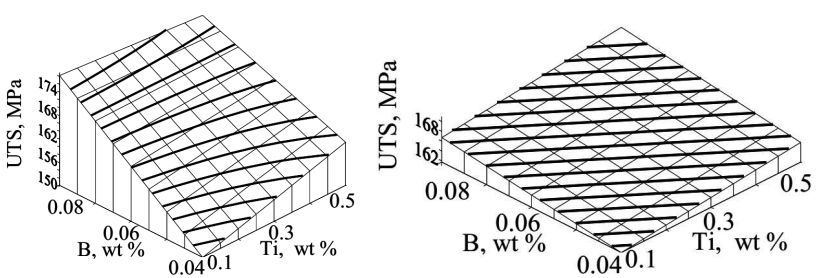

Fig. 2. The ultimate tensile strength (UTS) Al$9 \% \mathrm{SiMg}$ alloy with $\mathrm{B} \in\langle 0.04,0.08\rangle[\%]$ and $\mathrm{Ti} \in$ $\langle 0.1,0.3\rangle[\%]$ for $\mathrm{Al}+1 \%$ (left) and for $\mathrm{Al}+5 \%$ (right).
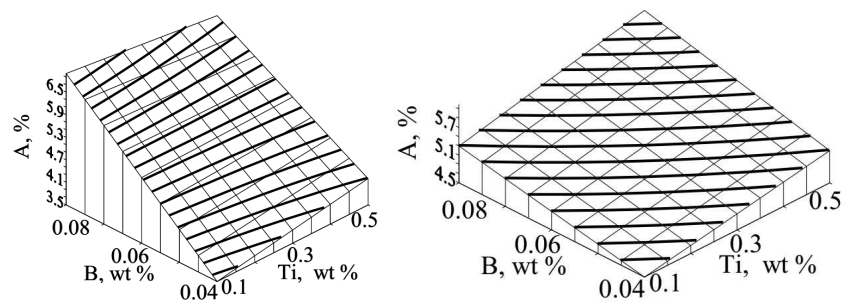

Fig. 3. Percentage elongation (A) Al-9\% $\mathrm{SiMg}$ alloy with $\mathrm{B} \in\langle 0.04,0.08\rangle[\%]$ and $\mathrm{Ti} \in\langle 0.1,0.3\rangle[\%]$ for $\mathrm{Al}+1 \%$ (left) and for $\mathrm{Al}+5 \%$ (right).
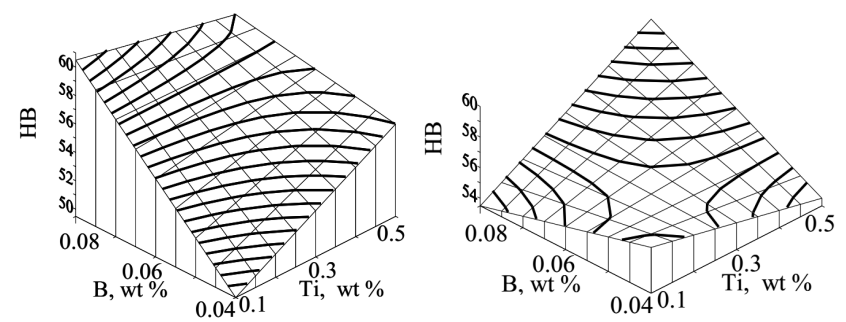

Fig. 4. Brinell hardness (HB) Al-9\% $\mathrm{SiMg}$ alloy with $\mathrm{B} \in\langle 0.04,0.08\rangle[\%]$ and $\mathrm{Ti} \in\langle 0.1,0.3\rangle[\%]$ for $\mathrm{Al}+1 \%$ (left) and for $\mathrm{Al}+5 \%$ (right).

In a non-modified $\mathrm{Al}-9 \% \mathrm{SiMg}$ alloy, ultimate tensile strength UTS was determined at $142 \mathrm{MPa}$, elongation $A$ at $1.8 \%$, and the Brinell hardness at $50 \mathrm{HB}$. Treatment with $1 \% \mathrm{Al}+0.04 \% \mathrm{~B}+0.1 \% \mathrm{Ti}$ a little increased ultimate tensile strength to $150 \mathrm{MPa}$ and elongation to $3.5 \%$ Brinell hardness is the same. An increase in the $\mathrm{B}$ content of the modifier to $0.08 \%$ increased tensile strength by $26 \mathrm{MPa}$ to $176 \mathrm{MPa}$ (Fig. 2 left) (increased by $34 \mathrm{MPa}$ comparison to raw alloy), elongation by $3.5 \%$ to $7.0 \%$ (Fig. 3 left) and hardness by $11 \mathrm{HB}$ to $61 \mathrm{HB}$ (Fig. 4 left). An next increase in the $\mathrm{Ti}$ content of the modifier to $0.5 \%$ decreased tensile strength by $2 \mathrm{MPa}$ to $174 \mathrm{MPa}$ (Fig. 2 left), elongation by $0.5 \%$ to $6.5 \%$ (Fig. 3 right) and hardness to $59 \mathrm{HB}$ (Fig. 4 right). For all modifiers on higher level tensile strength is $172 \mathrm{MPa}$ (Fig. 2 right), elongation $6.2 \%$ (Fig. 3 right) and hardness $60 \mathrm{HB}$ (Fig. 4 right).

The SEM micrographs of fractured surface of tensile test specimens of $\mathrm{Al}-9 \% \mathrm{SiMg}$ alloy tested with 
$1 \% \mathrm{Al}+0.04 \% \mathrm{~B}+0.1 \% \mathrm{Ti}$ is shown in Fig. 5 , and with $5 \% \mathrm{Al}+0.08 \% \mathrm{~B}+0.5 \% \mathrm{Ti}$ in Fig. 6. After modifications the fracture surface consists of cleavage planes and grain boundaries. It is a mixed pattern of transgranular and intergranular fracture.

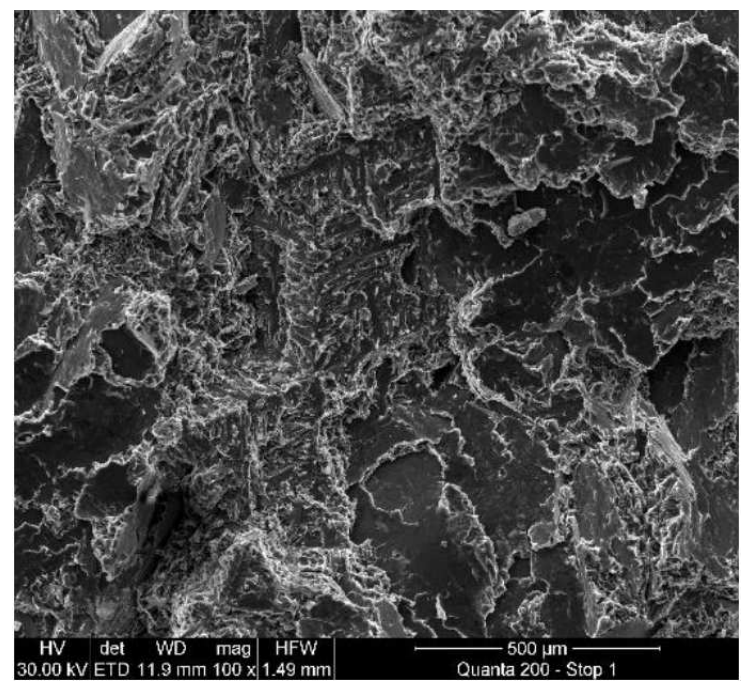

Fig. 5. SEM micrographs of fractured surfaces of Al$9 \% \mathrm{SiMg}$ alloy with $1 \% \mathrm{Al}+0.04 \% \mathrm{~B}+0.1 \% \mathrm{Ti}$.

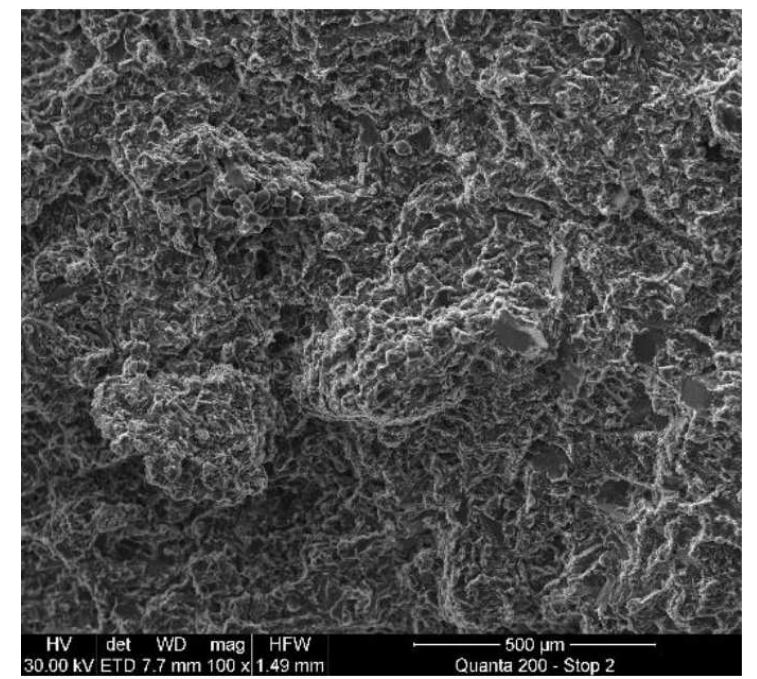

Fig. 6. SEM micrographs of fractured surfaces of Al$9 \% \mathrm{SiMg}$ alloy with $5 \% \mathrm{Al}+0.08 \% \mathrm{~B}+0.5 \% \mathrm{Ti}$.

\section{Conclusions}

Based on the results obtained in this work the following conclusions could be drawn:

- quantitative X-ray analysis of $\mathrm{Al}-9 \% \mathrm{SiMg}$ alloy confirms the introduction of boron and titanium with a modifier to the tested alloy; $\mathrm{Al}-\mathrm{Ti}$ and $\mathrm{Ti}-\mathrm{B}$ phases may be formed during the modifier manufacturing step then survived in liquid $\mathrm{Al}-\mathrm{Si}$ alloy modifying it;

- the highest: tensile strength UTS=176 MPa, percentage elongation $A=7 \%$, and the Brinell hardness 61 HB were achieved by enriching the alloy with a fast cooling mixture of $1 \% \mathrm{Al}+0.1 \% \mathrm{Ti}+0.08 \% \mathrm{~B}$;

- in this work it has been shown that the use of rapidly cooled alloys as a modifier is more effective than modifiers produced in traditional methods. In this way modifier elements with $\mathrm{Al}$ have higher efficiency than boron.

\section{References}

[1] R. Cupryś, B. Major, W. Wołczyński, Mater. Sci. Forum 329-330, 161 (2000).

[2] W. Kurz, D.J. Fisher, Fundamentals of Solidifications, Trans Tech Publ., 1992.

[3] W. Pilarczyk, Cryst. Res. Technol. 50, 700 (2015).

[4] J. Selejdak, R. Ulewicz, M. Ingaldi, in: Proc. 23rd Int. Conf. on Metallurgy and Materials, Ostrava 2014, p. 1882.

[5] Z. Poniewierski, Crystallization, Structure and Silumin Properties, WNT, Warsaw 1989.

[6] W. Wołczyński, E. Guzik, W. Wajda, D. Jędrzejczyk, B. Kania, M. Kostrzewa, Archiv. Metall. Mater. 57, 105 (2012).

[7] Ł. Rogal, J. Dutkiewicz, A. Góral, B. OlszowskaSobieraj, J. Dańko, Int. J. Mater. Form. 3, 771 (2010).

[8] S.J. Grauer, E.J.F.R. Caron, N.L. Chester, M.A. Wells, K.J. Daun, J. Mater. Process. Technol. 216, 89 (2015).

[9] T. Lipiński, Archiv. Metall. Mater. 60, 329 (2015).

[10] T. Lipiński, Archiv. Metall. Mater. 53, 193 (2008).

[11] T. Lipinski, P. Szabracki, Archiv. Metall. Mater. 58, 453 (2013).

[12] J. Pietraszek, E. Skrzypczak-Pietraszek, Adv. Mater. Res. 874, 151 (2014).

[13] W. Pilarczyk, A. Pilarczyk, Mater. Techn. 49, 537 (2015).

[14] A. Wrobel, B. Kucharska, Arch. Metall. Mater. 55, 205 (2010).

[15] W. Wołczyński, R. Cupryś, B. Major, Archiv. Metall. 43, 309 (1998).

[16] O. Kon, U. Sen, Acta Phys. Pol. A 127, 1214 (2015). 